\title{
Differential Occupation of Available Coral Hosts by Coral-Dwelling Damselfish (Pomacentridae) on Australia's Great Barrier Reef
}

\author{
Tory J Chase * (D) and Mia O Hoogenboom
}

Marine Biology and Aquaculture Group, College of Science and Engineering, and ARC Centre of Excellence for Coral Reef Studies, James Cook University, Townsville QLD 4811, Australia; mia.hoogenboom1@jcu.edu.au

* Correspondence: tory.chase@my.jcu.edu.au

Received: 14 October 2019; Accepted: 8 November 2019; Published: 15 November 2019

\begin{abstract}
Associations between habitat-forming, branching scleractinian corals and damselfish have critical implications for the function and trophic dynamics of coral reef ecosystems. This study quantifies how different characteristics of reef habitat, and of coral morphology, determine whether fish occupy a coral colony. In situ surveys of aggregative damselfish-coral associations were conducted at 51 different sites distributed among 22 reefs spread along $>1700 \mathrm{~km}$ of the Great Barrier Reef, to quantify interaction frequency over a large spatial scale. The prevalence of fish-coral associations between five damselfish (Chromis viridis, Dascyllus aruanus, Dascyllus reticulatus, Pomacentrus amboinensis and Pomacentrus moluccensis) and five coral species (Acropora spathulata, Acropora intermedia, Pocillopora damicornis, Seriatopora hystrix, and Stylophora pistillata) averaged 30\% across all corals, but ranged from $<1 \%$ to $93 \%$ of small branching corals occupied at each site, depending on reef exposure levels and habitat. Surprisingly, coral cover was not correlated with coral occupancy, or total biomass of damselfish. Instead, the biomass of damselfish was two-fold greater on sheltered sites compared with exposed sites. Reef habitat type strongly governed these interactions with reef slope/base (25\%) and shallow sand-patch habitats (38\%) hosting a majority of aggregative damselfish-branching coral associations compared to reef flat $(10 \%)$, crest $(16 \%)$, and wall habitats $(11 \%)$. Among the focal coral species, Seriatopora hystrix hosted the highest damselfish biomass ( $12.45 \mathrm{~g}$ per occupied colony) and Acropora intermedia the least (6.87 g per occupied colony). Analyses of local coral colony traits indicated that multiple factors governed colony usage, including spacing between colonies on the benthos, colony position, and colony branching patterns. Nevertheless, the morphological and habitat characteristics that determine whether or not a colony is occupied by fish varied among coral species. These findings illuminate the realized niche of one of the most important and abundant reef fish families and provide a context for understanding how fish-coral interactions influence coral population and community level processes.
\end{abstract}

Keywords: coral-fish association; symbiosis; habitat structure; prevalence; damselfish; coral reefs; biological interactions

\section{Introduction}

Scleractinian corals are the predominant habitat-forming organisms within coral reef ecosystems contributing to the (i) overall structure of reef habitats [1], (ii) co-existence and biodiversity of reef associated species [2-4], and (iii) providing critical microhabitats used by specialist species [5-8]. Consequently, the abundance of coral-dwelling and reef-associated species (e.g., crustaceans, sponges, bryozoans, fishes) is influenced by the abundance of habitat-forming corals [2,9], as well as by the structural complexity provided by coral-rich habitats [4,10-12], and the diversity of corals [13]. 
Importantly, high coral cover and habitat complexity moderate predation [14] and competition [15] among reef fish species. Meanwhile, fishes that have an intimate and obligate reliance on live corals for shelter (e.g., coral Gobiidae spp. [16], coral-dwelling Pomacentridae spp. [7]) or food (e.g., coral-feeding Chaetodontidae spp. [17]), often have specific preferences for select coral species which, themselves, might occur only in certain habitats (under certain environmental conditions or shelf positions [18]). Ultimately, corals might be a limiting resource that regulates the distribution and abundance of many reef fishes [6,19], depending on their specificity to particular coral species and their reliance on live coral habitats. Understanding this process requires intensive and broad-scale quantification of fish-coral interactions to distinguish effects of habitat types from the effects of coral cover.

The abundance of suitable coral, that enable long-term usage or residency of associated fauna across various life stages, is one of the most importance factors dictating damselfish presence [20,21], evident by the fact that abundances of fishes and motile invertebrates' abundances decline sharply following coral mortality $[19,22]$. Despite a strong dependence on corals by several fish families, not all coral colonies are occupied by fishes due to physical and behavioural limitations [7,21]. At a larger spatial scale of reefs and latitude, local availability of specific types of habitat determine spatial distribution patterns in habitat-specialized fish, (i.e., Gobiodon spp., [23,24]). However, to determine the extent to which the availability of specific coral habitats constrain the abundance of reef fishes, direct measurement of the abundance of fishes on individual coral colonies is required. Previous studies have linked variation in damselfish's abundance and diversity with habitat-related variation in the percentage cover or functional diversity of corals $[18,25]$, but have not assessed whether and how features of coral colonies within habitats also influence fish abundance. Assessment of fish-coral interactions at the colony level is important, because this is the scale at which impacts of damselfish on corals are the most prevalent $[26,27]$. Services that fish provide to corals are often density-dependent (such as nutrient provision) and are heavily dependent on fish biomass [26,28]. Furthermore, understanding the spatial variation in coral-dwelling fish provides a context for understanding how these fish influence coral populations and communities, and how these mutualisms are likely to change during external disturbances and degradation.

Habitat type and colony morphology influence the suitability of coral hosts for nearly all types of coral-associated fauna, especially fishes, as observed for both Scleractinian and Alcyonacean corals [29-32]. This colony-scale association correlates with fish size [33], with how fish utilize the coral, and with fish diet preferences, and social and spatial niches [29,34,35]. Indeed, seascape and colony features strongly influence feeding behaviour, especially for zooplankton feeding damselfishes for which among-species partitioning of planktonic prey dictates how different fish species are distributed among reef zones [36-38]. Moreover, for other fish taxa, including Pomacentridae, Gobiidae, and Blennidae, fine-scale $\left(1\right.$ to $\left.10 \mathrm{~cm}^{2}\right)$ differences in the suitability of coral hosts depends on much more than just the coral taxonomic identity. For example, Dascyllus marginatus and other aggregating damselfish are more likely to inhabit colonies with fine branches, compared with lobed branching morphologies, as inter-branch space is a limiting determinant for these fishes [21,39]. Furthermore, seascape features such as distance from the reef's edge and water flow velocities govern species-specific patterns and biomass due to fishes' swimming ability, plankton/prey availability, trophic specializations [37], and colony arrangement requirements; this has been demonstrated in habitat-specialist/coral dwelling and non-coral-dwelling fishes [38,40-43]. However, the specific reef habitat characteristics, and with both within- and among-species variation in coral colony structures, that promote occupancy and residency by aggregative damselfish has yet to be fully understood, with most of this work to date focusing on Blennidae and Gobiidae that usually inhabit corals as individuals or pairs rather than in large aggregations [23]. Aggregative species are likely to utilize different resources and have different association levels compared with large transient and/or small solitary species [44].

This research explores the large-scale spatial variation in occupancy rates and biomass of coral-dwelling damselfish among predominant habitat-forming scleractinian coral species, and assesses specific habitat and colony features that influence whether or not individual coral 
colonies are used by coral-dwelling, planktivorous damselfish. The prevalence of fish-coral interactions is examined for five damselfish (Chromis viridis, Dascyllus aruanus, Dascyllus reticulatus, Pomacentrus amboinensis, and Pomacentrus moluccensis) on five coral species (Acropora spathulata, Acropora intermedia, Pocillopora damicornis, Seriatopora hystrix, and Stylophora pistillata). These corals are frequently occupied by coral-dwelling damselfish [5,21,45-47]. Previous research demonstrates that these select coral and fish species can account for $>70 \%$ of non-cryptic fish-coral interactions within the Great Barrier Reef [21,47] and play important roles in assimilating energy and nutrients from plankton into the reef food web. Each of these Pomacentrid sp. have been documented to be 'coral-dwelling' with a home range of a single coral or similar $<2 \mathrm{~m}$ structure $[18,27,39,48,49]$. Finally, the focal fish species represent important prey for meso- and top predators [18] and are therefore important in reef trophic dynamics. Multiple coral colony traits were measured in situ as these traits are hypothesized to correlate with patterns of fish occupation and biomass. This study increases the number studies that have quantified broad-scale abundance of damselfish associated with different colony morphologies. We investigate the distribution of these coexisting damselfish within and among reef zones to (a) determine if suitable coral habitat governs patterns in damselfish's distribution and abundance (large scale, $>10 \mathrm{~m}$, based on variation in coral cover among reefs), and (b) quantify variations in fish biomass within and among coral colony species (small scale $>1 \mathrm{~m}$, based on observations of individual coral colonies). Evaluating the multiscale spatial variation of fish-coral interactions provides insight into fishes' effects on coral health, and context for predicting the functioning of interspecific and symbiotic associations during global environmental change.

\section{Materials and Methods}

\subsection{Study Sites and Surveys}

This study was conducted in March-November 2016, in the northern Great Barrier Reef (GBR), Australia. Surveys were conducted at 51 study sites across 20 different reefs (Figure 1 ) including the far northern sector ( $n=11$ sites), the northern sector ( $n=24)$ including Lizard Island sites ( $n=16$ sites), the central sector $(n=13$ sites) and the southern sector near One Tree Island ( $n=3$ sites, see Table 1$)$.

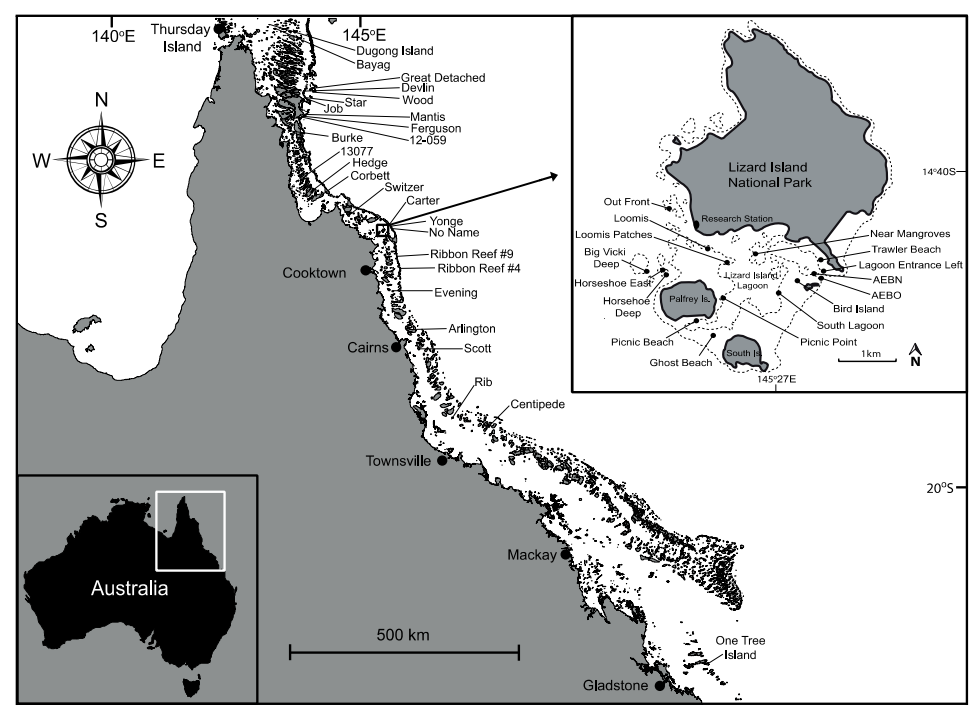

Figure 1. Location of study reefs (for reef seascape surveys and colony level surveys) along the Great Barrier Reef (GBR, 51 sites spread among 22 different reefs), spanning $>1700 \mathrm{~km}$ (map modified from [50]) with Lizard Island subset including 16 sites, surveyed between February and November 2016. Some reefs contained more than one transect. Map template is provided by Geoscience Australia under a Creative Commons Attribution 4.0 International License. 
Table 1. Dataset summaries detailing the (a) observed site features quantified for 51 sites, and the individual coral (b) colony orientation, and (c) colony structure for 226 individual colonies with and without resident damselfish (occupancy and biomass as independent variables) on mid-shelf and offshore GBR reefs. Coral-fish interactions were focused on five focal fish species (Chromis viridis, Dascyllus aruanus, Dascyllus reticulatus, Pomacentrus amboinensis, and Pomacentrus moluccensis) occupying five common branching morphologies (Acropora intermedia, Acropora spathulata, Pocillopora damicornis, Seriatopora hystrix, and Stylophora pistillata).

\begin{tabular}{|c|c|}
\hline (a) Reef Seascape Surveys: & Description of Data \\
\hline \multicolumn{2}{|c|}{$\begin{aligned} \text { Sampling: } 50 \times 5 \text { belt transects } n=3097 \text { colonies on } 51 \text { sites spread among } 22 \text { reefs, including sheltered }(n=28 \text { sites }) \text { and exposed ( } n=23 \text { sites) sites, and sand patches }(n=11 \text { sites), } \\
\text { reef flat }(n=5 \text { sites), reef crest }(n=12 \text { sites), reef wall }(n=5 \text { sites), and reef slope }(n=18 \text { sites }) \text { habitats. }\end{aligned}$} \\
\hline Latitude & $\begin{array}{l}\text { Sites grouped by latitude: Far north }\left(12.3^{\circ} \mathrm{S} \text { to } 10.5^{\circ} \mathrm{S}\right), \text { North }\left(12.3^{\circ} \mathrm{S}\right) \text {, Central }\left(14.7^{\circ}\right. \\
\left.\left.\mathrm{S} \text { to } 18.9^{\circ} \mathrm{S}\right) \text { and South (One Tree Island, } 23.5^{\circ} \mathrm{S}\right)\end{array}$ \\
\hline Aspect & $\begin{array}{l}\text { Exposed locations (high water flow, mainly eastern side of GBR reefs) vs sheltered } \\
\text { locations (low water flow, mainly western side of GBR reefs) }\end{array}$ \\
\hline Habitat Zone & Lagoon sand patch, reef flat, reef crest, reef wall, and reef slope/base \\
\hline Benthic cover [51] & $\begin{array}{l}\text { Percentage cover measured on four } 10 \mathrm{~m} \text { line intercept transects at each site using the } \\
\text { following categories: Isopora, Montipora, tabular Acropora, staghorn Acropora, } \\
\text { other Acropora, Pocillopora damicornis, Seriatopora, Stylophora, other pocilloporids, } \\
\text { Mussidae, Faviidae, Poritidae, other scleractinians, soft corals, and other sessile fauna }\end{array}$ \\
\hline Coral Species & $\begin{array}{c}\text { Acropora intermedia, Acropora spathulata, Pocillopora damicornis, Seriatopora hystrix, } \\
\text { and Stylophora pistillata }\end{array}$ \\
\hline \multicolumn{2}{|c|}{ (b) Colony orientation: Sampling: Digital photos of $n=226$ colonies on 15 sites on 11 exposed and sheltered reefs } \\
\hline Colony Orientation [52] (Position of Coral on Substratum) & $\begin{array}{l}\text { Crevice—colony grew within a crack in the reef matrix; Open—colony is on flat reef } \\
\text { benthos without any obvious shading by competitors; Sand-colony grew above } \\
\text { a sand patch; Underhang—colony was shaded by reef matrix or other colonies }\end{array}$ \\
\hline \multicolumn{2}{|c|}{ (c) Colony structure: Sampling: Digital photos of $n=226$ colonies on 15 sites on 11 exposed and sheltered reefs } \\
\hline Colony Diameter & $\begin{array}{l}\text { Average of the longest colony diameter dimension and the diameter perpendicular to } \\
\text { that dimension }\end{array}$ \\
\hline \multirow{3}{*}{$\begin{array}{l}\text { Planar Area } \\
\text { Colony Height } \\
\text { Branch Width }\end{array}$} & Digitally traced along colony perimeter \\
\hline & Distance from top of coral colony to substrate \\
\hline & Average width of branches $\left(n=5\right.$ branches colony $\left.{ }^{-1}\right)$ located throughout the colony \\
\hline Branch Spacing & $\begin{array}{c}\text { Average distance between branches }\left(n=5 \text { branches colony }{ }^{-1}\right) \text { located throughout the } \\
\text { colony }\end{array}$ \\
\hline Isolation & Distance to nearest branching, columnar, tabular, or foliaceous colony \\
\hline
\end{tabular}


Along latitudes spanning $>10^{\circ}, 1-3$ transects per site were compared to quantify occupancy and resident damselfish's biomass. Sites were either sheltered or exposed; western facing aspects (sheltered sites, often with sandy lagoons) receive less exposure of wave energy and weather, compared with eastern facing aspects (exposed) sites on the GBR, due to the geomorphology of the surveyed mid-shelf and off-shore reefs $[53,54]$. Transects were located within different habitat zones (sand patches, flat, crest, wall (distinguished from slope by approximately vertical relief of the substratum), slope/base (gentle gradient or approximately flat), at different distances from shore (mid-shelf and off-shore reefs), and at varying depths (0-14 m, standardized to Lowest Astronomical Tide (LAT)). Herein, occupancy is described as a colony being used as the sole site of shelter/habitat within a damselfish's territory or home range $[21,22,55]$. Surveys focused on five species of damselfish (Chromis viridis, Dascyllus aruanus, Dascyllus reticulatus, Pomacentrus amboinensis, and Pomacentrus moluccensis) and five species of branching corals (Acropora intermedia, Acropora spathulata, Pocillopora damicornis, Seriatopora hystrix, and Stylophora pistillata, see Figure S1 in Supplementary Materials). The host corals were selected for their abundance on the GBR, while also displaying differences in morphology, and particularly, branch spacing patterns due to the hypothesized role of branch spacing in determining colony occupancy $[9,56]$.

At each site, the abundance and occupation of colonies (20-100 $\mathrm{cm}$ in diameter) of each study species (Acropora intermedia, Acropora spathulata, Pocillopora damicornis, Seriatopora hystrix, and Stylophora pistillata) were recorded along a $50 \mathrm{~m} \times 5 \mathrm{~m}$ belt transect (total area of $250 \mathrm{~m}^{2}$ ) by scuba diving. We also recorded the size and abundance of focal fish species (Chromis viridis, Dascyllus aruanus, Dascyllus reticulatus, Pomacentrus amboinensis, and Pomacentrus moluccensis) within each colony through a visual census during scuba diving. Along each transect, each colony was slowly approached and observed for at least $30 \mathrm{~s}$ to determine damselfish species presence, size, and abundance for biomass estimates. For consistency, all coral and fish observations were performed by the same observer during daylight hours (between 8:00 and 18:00 h). In addition, four replicate $10 \mathrm{~m}$ line intercept transects were completed at each site to measure total coral cover (of all corals not just the 5 focal species $[51,57]$ ).

To assess whether occupation of focal coral species by the specific damselfish was influenced by intrinsic or extrinsic factors, we measured a series of colony attributes for a subset of colonies $(n=226)$ at 15 different sites. These colonies were located on 11 exposed and sheltered reefs, spanning habitats at a depth range of 0-13 m, positioned in the Far North, North, Central, and Southern GBR regions as described above (see Tables S3-S5 in Supplementary Materials for details). Colony position was categorized as being either within a crevice, on an overhang, on open carbonate pavement, or on sand [52]. Colony structure traits measured included: colony size (colony diameter, planar area, and colony height), distance from nearby corals (isolation), and branch dimensions (i.e., inter-branch spacing and average branch width $[47,58]$, see Table 1 and Figure S2 in Supplementary Materials). Branch spacing and branch width were averaged for five measurements around each colony, with all branch measurements taken at $\sim 15 \mathrm{~mm}$ from the branch tip, while colony isolation being measured as the distance to the closest habitat providing coral (i.e., branching or other complex morphology colonies). For colonies with resident fishes $(n=142)$, the numbers of all fishes on each focal colony were recorded, and all fish were placed into general standard-length size classes of small, medium, and large, for each species respectively. Size class data were subsequently converted into biomass estimates, based on published length/weight relationships generated from damselfish [27,47], where damselfish were collected using hand-nets and a liquid anesthetic (a diluted solution of clove oil, ethanol, and seawater $[27,59,60])$. Surveys focused on ecologically important damselfish's occupancy and biomass patterns rather than fish numbers, as biomass has been directly linked to fish-derived services and benefits for corals [26,61]. For the purposes of these surveys, fish biomass summarizes both fish numbers and size, and the analysis did not delineate which of these components contribute more to biomass levels. Additional details of transects, sites and colonies are provided in Table 1 and Supplementary Tables S3-S5. 


\subsection{Data Analysis}

\subsubsection{Reefscape Prevalence of Fish-Coral Interactions}

At the reef seascape level, the proportion of colonies occupied by fish (all damselfish and coral species pooled, as the independent variable) varied on each transect, and was analysed using a full additive beta regression model with latitude, aspect (exposure level), habitat, and coral cover as fixed dependent factors, and reef as a random factor. A beta regression was deemed appropriate, as it includes a logit transformation which is necessary for proportional data $[62,63]$. The appropriateness of the models selected were confirmed by assessing quantile, or Q-Q plots for normality and residual plots for homogeneity of variance and linearity, as well as calculations of dispersion. Additive models (latitude + aspect + habitat + coral cover) were used due to the non-factorial nature of the dataset wherein not all habitats and aspects could be sampled at each latitude.

A linear mixed-effect model (LME) was used to analyse effects of latitude, aspect, habitat, and coral cover, on total biomass of focal damselfish species (grams per $250 \mathrm{~m}^{2}$ ), $\log +1$ transformed, recorded on each transect. The fish biomass LME was fitted using maximum likelihood [64]. Model selection, based on Akaike information criteria (AIC) values, was implemented to determine the importance of latitude, aspect, habitat, and coral cover as predictors of fish biomass (following [65,66], see below) and assumptions for model validity were checked through Q-Q plots (normality) and residual plots (homogeneity of variance and linearity), as well as calculations of dispersion. In addition, the multi-model interference R package MuMIn, was used to perform model selection on proportion of colonies occupied and total biomass models based on model weights derived from AICc. MuMIn allows for an estimate of the variance explained by all factors included in the model (R package MuMIn, $[67,68]$ ). A ranking of the possible models to identify the contribution/importance of each variable as well as the number of models in which each variable was completed (function "dredge" in R package $M u M I n)$.

To compare differences in total occupancy (only occupied colonies, $n=898$ ) among each of the five coral species, binomial generalized linear models (GLMs) with Tukey's honestly significant difference (HSD) post hoc (with Bonferroni adjusted $p$-values) were used. Total damselfish's biomass was analyzed using a Gaussian GLM with Tukey's HSD post hoc. Separate Kruskal-Wallis rank sum tests were performed for each damselfish species to analyse whether coral species identity (independent variable) affected the biomass of different species of resident damselfish (dependent variable) on these 898 occupied colonies. Kruskal-Wallis tests were deemed appropriate as fish biomass data did not meet assumptions of homogeneity of variance and normality. Dunn tests were used for multiple post hoc comparisons between species due to unequal sample sizes, and $p$-values were adjusted with the Benjamini-Hochberg method to decrease type I error; the Benjamini-Hochberg method is a more powerful method than the Bonferroni correction to control the false discovery rate [69] and frequently used with the Kruskal-Wallis test.

\subsubsection{Effects of Colony Position and Structure on Damselfish's Occupancy}

To compare how colony position and structure impacted occupation and biomass for a subset of colonies, principle component analyses (PCAs) were used to evaluate overall differences in colony morphology between corals with $(n=142)$ and without fish $(n=84)$, both with data pooled over all corals $(n=226)$, and separately for each coral species (using the colony level dataset). These different analyses were conducted to assess whether there were particular colony structure traits that influenced fish presence overall, and whether such features were consistent among coral species. PCAs were deemed appropriate due to the multivariate nature of the data with variables (e.g., branch width and branch spacing) that were likely to be correlated with each other. The PCA ordinated colonies were based on the standardized correlation matrix between colony attributes using the $\mathrm{R}$ function princomp [70,71]. Subsequently, the principle component (PC) 1 and 2 scores of each colony were used to represent the overall variation in colony morphology in subsequent linear models (LM) of fish 
occupation (presence/absence). To further differentiate occupancy patterns between the colony position, a binomial GLM was used with a Tukey's HSD post hoc to assess between factor level differences. A lognormal linear model was used to quantify total damselfish's biomass (only occupied colonies) with regards to colony position, again with Tukey's HSD post hoc comparisons.

Similarity percentage analysis (SIMPER [71-73]) was used to determine which coral structure traits (colony diameter, planar area, colony height, branch spacing, branch width, and isolation) contributed the most to the differences among corals with and without fish. This analysis compared the importance of these structural traits for all coral species pooled and pooled across the different species of fish occupying these corals. The SIMPER analysis was performed on the PCA standardized data to assess which structure traits were driving the differences (by individual coral species and species pooled) and ranked in order according to their contribution (\% or importance ranking). This similarity percentage is based on the decomposition of Bray-Curtis dissimilarity index, giving the overall contribution of individual structure traits.

\subsubsection{Effects of Colony Position and Structure on the Biomass of Damselfish}

Total biomass of damselfish on colonies located in different reef microhabitats (colony orientation, Table 1) were analysed with lognormal linear models. Model fit was assessed using residual plots, all of which were satisfactory (normal and homogenous). As total pooled damselfishes' biomass is a continuous variable, a series of linear models per individual coral species and for all colonies pooled were completed to determine if total damselfishes' biomass (dependent variable) varied with the two most important structure traits (independent variables) from the SIMPER of colony structure occupancy.

All data analyses were performed in the statistical software R [74] using the betareg [62], multcomp [75], lsmeans [76], simper function in vegan, and MuMIn [67,68] packages. Full datasets are available at [77].

\section{Results}

\subsection{Range of Damselfish's Occupations across the Great Barrier Reef (GBR)}

In transect-based surveys, a total of 5154 damselfish of the five focal species (Chromis viridis, Dascyllus aruanus, Dascyllus reticulatus, Pomacentrus amboinensis, and Pomacentrus moluccensis) were counted on 3034 coral colonies of the five focal species (Acropora intermedia, Acropora spathulata, Pocillopora damicornis, Seriatopora hystrix, and Stylophora pistillata) on 51 transects (with combined sample area of $12,750 \mathrm{~m}^{2}$ ). Overall, $30 \%$ of colonies were occupied by one or more of the focal damselfish species (898 out of 3034, all transects pooled). Single-species groups of Pomacentrus moluccensis or Dascyllus aruanus were recorded on $80 \%$ of occupied colonies. P. moluccensis were prevalent (in terms of coral host occupancy) in all habitats, while Chromis and Dascyllus species almost exclusively inhabited corals on sand-patch and slope habitats (Figure S2 in Supplementary Materials).

Occupancy varied with aspect and habitats, with values ranging from $0 \%$ at exposed, flat and crest habitat zones, up to $93 \%$ at sheltered sand-patch habitats. In the full model, habitat (1) and aspect (2) were the most important variables in predicting fish occupancy (Table S1 in Supplementary Materials). In general, occupancy levels were higher in western aspect/sheltered sites locations (including lagoons) than eastern aspect/exposed sites (betareg (logit): $p=0.002$ ), and highest numbers were observed in sand patches and slope habitats $(p=0.016$, Figure $2 b)$. Latitude $(p=0.051)$, and coral cover $(p=0.735)$ were not significant predictors of the proportion of colonies occupied (Figure 2a,b). 
(a)

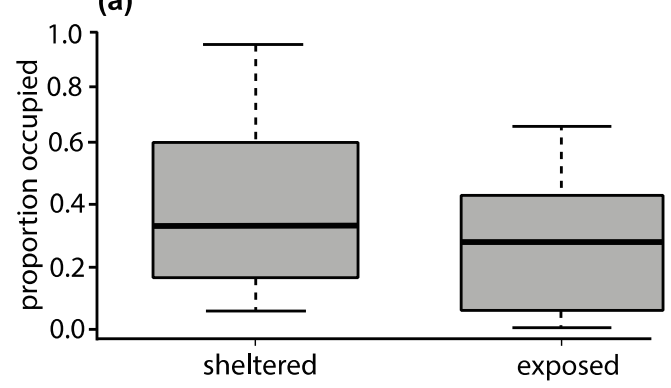

(c) (b)

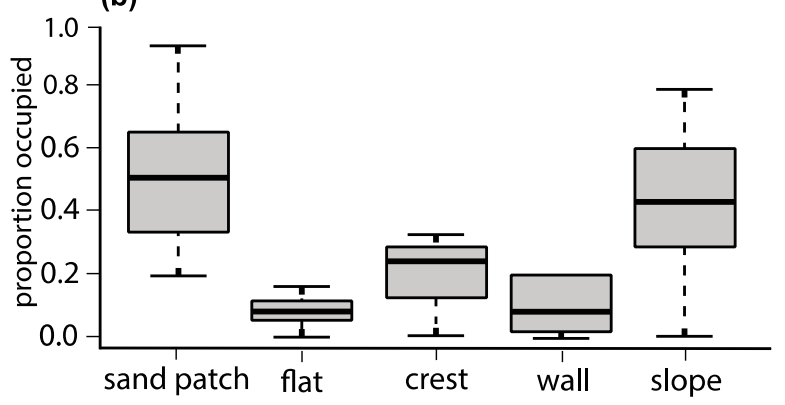

(d)
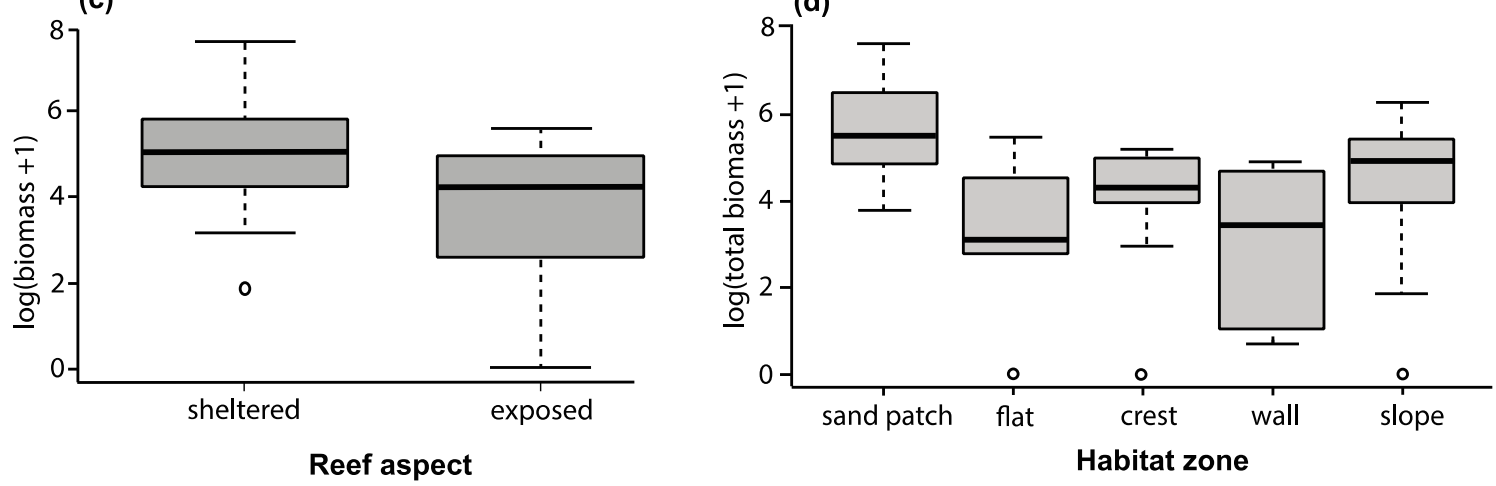

Figure 2. Boxplots (horizontal lines show median; boxes indicate 25th and 75th percentiles; vertical dotted lines show range; data points show outliers) of colonies occupied (reef seascape) (a,b) and damselfish's biomass $(\log +1)$ abundance $(\mathbf{c}, \mathbf{d})$ on five species of branching coral (Acropora intermedia, Acropora spathulata, Pocillopora damicornis, Seriatopora hystrix, and Stylophora pistillata) in relation to aspect category (exposed or sheltered) and reef habitat (sand patches, flat, crest, wall, and slope/base).

Additionally, occupancy also varied with coral species (binomial GLM, significant effect of species, $p<0.05$ ). Both $P$. damicornis (34\% occupancy) and Stylophora pistillata (33\% occupancy) had the highest average occupancy, when compared with Acropora spathulata (30\%), S. hystrix (23\%), and Acropora intermedia (22\%) (see Table 2 for post hoc comparisons and Table S2 for the binomial GLM output). These damselfish species-specific occupancy patterns translated into different damselfish diversity and biomass on each coral species (Tables S3-S5 in Supplementary Materials); for instance, Acropora intermedia, Pocillopora damicornis, and Stylophora pistillata hosted mainly Dascyllus aruanus and Pomacentrus moluccensis aggregations, while Acropora spathulata hosted Chromis viridis and Pomacentrus moluccensis heterospecific groups.

Table 2. Multiple comparisons of coral-species, with $p$-values, (Tukey's honestly significant difference (HSD) post hoc) based on a binomial generalized linear model of colony occupancy with damselfish species pooled (reef seascape dataset): colony occupancy (dependent) and colony species (independent variable). Significant $p$-values are in bold.

\begin{tabular}{cc}
\hline Comparison & $p$-Value \\
\hline A. intermedia - A. spathulata & 0.5089 \\
A. intermedia - P. damicornis & $\mathbf{0 . 0 0 5 0}$ \\
A. intermedia - S. hystrix & 0.9996 \\
A. intermedia - S. pistillata & $\mathbf{0 . 0 1 3 1}$ \\
A. spathulata - P. damicornis & 0.8963 \\
A. spathulata - S. hystrix & 0.4492 \\
A. spathulata - S. pistillata & 0.9588 \\
P. damicornis - S. hystrix & $<\mathbf{0 . 0 0 1}$ \\
\hline
\end{tabular}




\subsection{Patterns of Damselfish Biomass across Reefs on Occupied Colonies}

An average of six damselfish were present on each occupied colony. Pomacentus amboinensis was the most prevalent damselfish species on the coral colonies considered during this study, present on nearly half of all occupied coral colonies ( 2.3 Pomacentus moluccensis colony $\left.{ }^{-1}\right)$, and accounting for $\sim 45 \%$ of all damselfish's biomass on coral hosts (Table 3, Figure 3, and Tables S3-S5 and Figure S3 in Supplementary Materials). Dascyllus aruanus was the second most abundant with an average 1.8 fish per occupied colony $^{-1}$ and the other three species were present at considerably lower abundance (Chromis viridis: 0.8 fish occupied colony ${ }^{-1}$, Dascyllus reticulatus 0.2 fish occupied colony ${ }^{-1}$, and Pomacentrus moluccensis: 0.5 fish occupied colony ${ }^{-1}$ ).

Damselfish's biomass was broadly similar to occupancy patterns, displaying significant differences in biomass per $250 \mathrm{~m}^{2}$ depending on aspect (LME $(\log +1)$, aspect, $\chi^{2}=6.88, p=0.008$, Figure $2 \mathrm{c}, \mathrm{d}$ ).

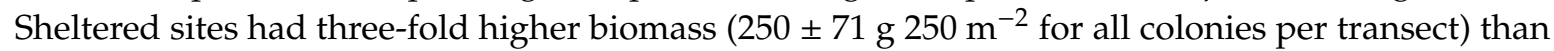

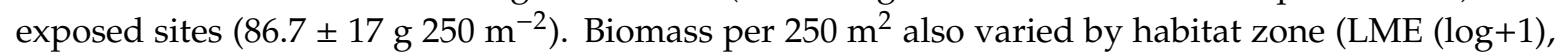

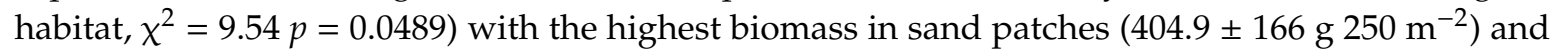

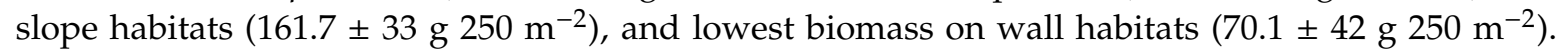
Again, latitude (LME $\left.(\log +1) \chi^{2}=2.81, p=0.42\right)$ and coral cover $\left(\chi^{2}=0.109, p=0.740\right)$ were not significant predictors of total fish biomass per transect. In the full model, aspect (1) and habitat (2) were the most important variables in predicting fish occupancy (Table S1 in Supplementary Materials).

Damselfish's biomass per occupied colony ranged from $1.3 \mathrm{~g}$ (a single Pomacentrus amboinensis) to $120 \mathrm{~g}$ (a school of $\sim 100$ Chromis viridis or a large aggregation of $\sim 30$ Dascyllus aruanus). Among the five fish species, Pomacentrus moluccensis exhibited the most consistent and broadest distribution being present in high biomass in every habitat zone. Seriatopora hystrix coral colonies hosted the highest fish biomass per occupied colony (12.45 $\mathrm{g} \pm 1.33$ ), with Acropora intermedia having the lowest biomass per occupied colony $(6.87 \mathrm{~g} \pm 1.33)$. As a result, total damselfish's biomass was significantly different among occupied coral species (GLM: $p=0.012$, see Supplementary Table S6 for post hoc comparisons). When data were analysed by fish species, the biomass of each damselfish species significantly varied among host coral species (see Table S7 in Supplementary Materials for post hoc comparisons), except for Chromis virdis (Kruskal-Wallis: $\chi^{2}=9.104, \mathrm{df}=4, p=0.0586$ ). Seriatopora hystrix and Pocillopora damicornis colonies were favoured by Dascyllus aruanus $\left(\chi^{2}=45.304, \mathrm{df}=4\right.$, $p<0.001)$ and Dascyllus reticulatus $\left(\chi^{2}=29.962, \mathrm{df}=4, p<0.001\right)$. Acropora spathulata and Stylophora pistillata colonies were favoured by Pomacentrus amboinensis $\left(\chi^{2}=11.715, \mathrm{df}=4, p=0.019\right)$ and Pomacentrus moluccensis $\left(\chi^{2}=29.962, \mathrm{df}=4, p<0.001\right)$. 
Table 3. Average biomass estimates (mean \pm SE) for each damselfish species (Chromis viridis, Dascyllus aruanus, Dascyllus reticulatus, Pomacentrus amboinensis, and Pomacentrus moluccensis) on each coral species (Acropora intermedia, Acropora spathulata, Pocillopora damicornis, Seriatopora hystrix, and Stylophora pistillata) on occupied colonies in sheltered and exposed aspect sites.

\begin{tabular}{|c|c|c|c|c|c|c|c|}
\hline \multirow[b]{2}{*}{ Aspect } & \multirow[b]{2}{*}{ Coral Species } & \multirow[b]{2}{*}{$n$} & \multicolumn{5}{|c|}{ Average Biomass (g) per Coral Species per Site Aspect } \\
\hline & & & C. viridis & D. aruanus & D. reticulatus & P. amboinensis & P. moluccensis \\
\hline \multirow{5}{*}{ Sheltered } & A. intermedia & 38 & $0.92 \pm 0.79$ & $2.21 \pm 0.96$ & $0.94 \pm 0.89$ & $1.06 \pm 0.31$ & $2.80 \pm 0.54$ \\
\hline & A. spathulata & 30 & $4.66 \pm 2.03$ & $0.60 \pm 0.48$ & $0.17 \pm 0.17$ & $0.09 \pm 0.06$ & $5.70 \pm 0.96$ \\
\hline & P. damicornis & 233 & $0.52 \pm 0.22$ & $5.00 \pm 0.79$ & $0.26 \pm 0.14$ & $0.84 \pm 0.12$ & $3.89 \pm 0.34$ \\
\hline & S. hystrix & 147 & $2.63 \pm 1.10$ & $8.49 \pm 1.15$ & $0.00 \pm 0.00$ & $0.63 \pm 0.11$ & $2.47 \pm 0.34$ \\
\hline & S. pistillata & 179 & $0.22 \pm 0.02$ & $4.72 \pm 0.64$ & $0.36 \pm 0.12$ & $0.50 \pm 0.99$ & $4.74 \pm 0.51$ \\
\hline \multirow{5}{*}{ Exposed } & A. intermedia & 16 & $0.19 \pm 0.19$ & $0.00 \pm 0.00$ & $0.00 \pm 0.00$ & $0.24 \pm 0.13$ & $3.91 \pm 1.06$ \\
\hline & A. spathulata & 6 & $0.00 \pm 0.00$ & $0.00 \pm 0.00$ & $0.00 \pm 0.00$ & $0.00 \pm 0.00$ & $9.18 \pm 3.31$ \\
\hline & P. damicornis & 86 & $0.24 \pm 0.23$ & $0.00 \pm 0.00$ & $1.52 \pm 1.03$ & $0.48 \pm 0.16$ & $6.45 \pm 1.00$ \\
\hline & S. hystrix & 42 & $0.00 \pm 0.00$ & $0.00 \pm 0.00$ & $0.04 \pm 0.04$ & $0.84 \pm 0.22$ & $5.38 \pm 0.89$ \\
\hline & S. pistillata & 121 & $0.00 \pm 0.00$ & $0.18 \pm 0.12$ & $0.22 \pm 0.11$ & $0.75 \pm 0.16$ & $5.79 \pm 0.50$ \\
\hline
\end{tabular}




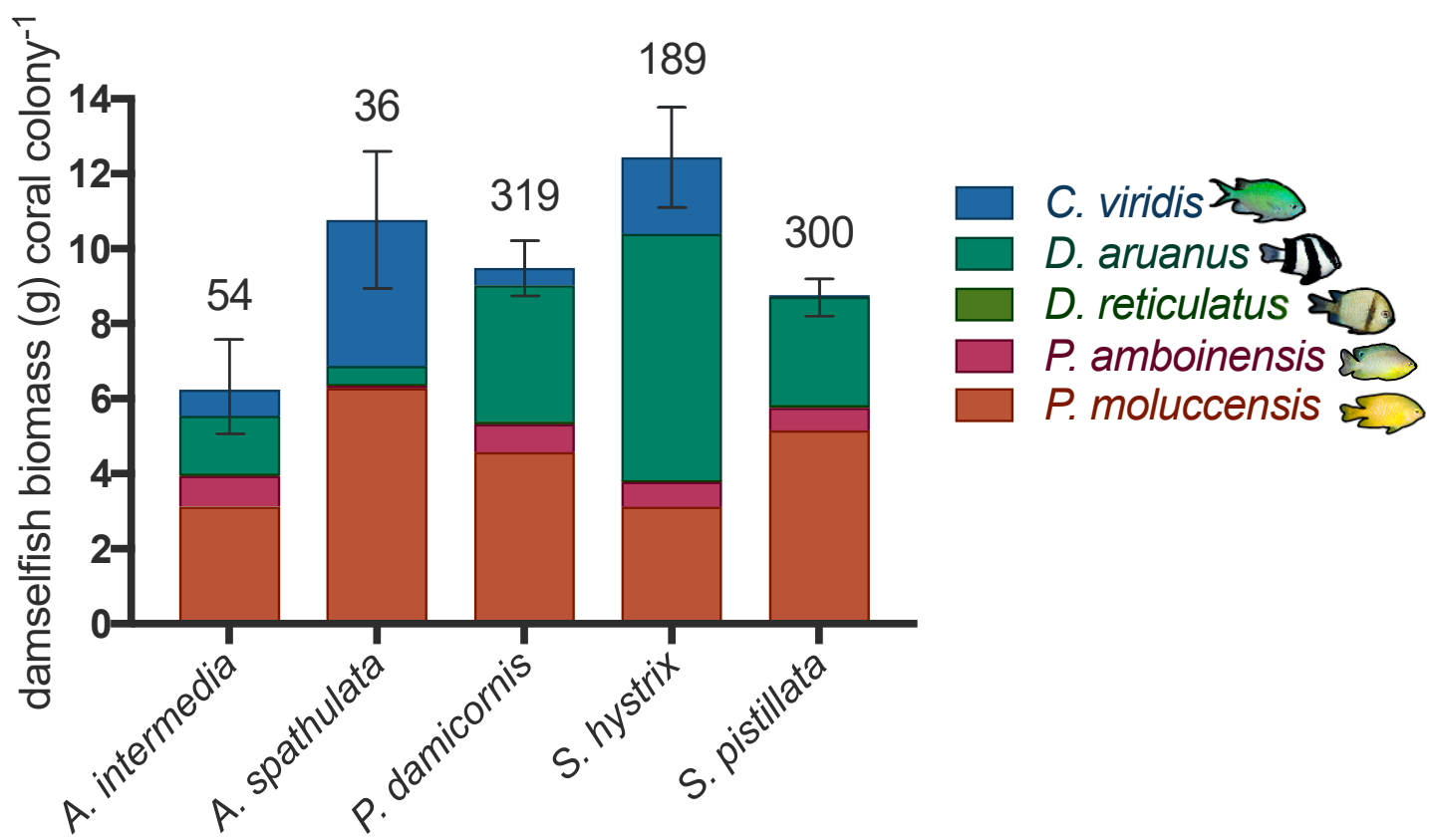

\section{Coral species}

Figure 3. Mean biomass per fish species ( $\mathrm{g} \pm$ standard error (SE) of total biomass of damselfish) per coral species (Acropora intermedia, Acropora spathulata, Pocillopora damicornis, Seriatopora hystrix, and Stylophora pistillata) for all occupied colonies $(n=898)$ for 5154 fish (Chromis viridis, Dascyllus aruanus, Dascyllus reticulatus, Pomacentrus amboinensis, and Pomacentrus moluccensis) at 51 sites. Coral sample sizes per species are displayed above the bars. Note the collapse of Dascyllus reticulatus and Pomacentrus amboinensis sub-bars for the Acropora spathulata coral bar, and again for Dascyllus reticulatus on the Seriatopora hystrix bar, indicating very low biomass values for these fish species on these corals. Further damselfish species-specific and coral species-specific average biomass $( \pm \mathrm{SE})$ per site aspect, and habitat are displayed in Supplementary Tables S3-S5).

\subsection{Colony Orientation as a Determinant of Damselfish's Occupation and Group Biomass}

Higher coral occupancy was observed on corals located in reef microhabitats that were either open carbonate pavement or open sandy substratum habitats (LM: (open) $p=0.0068$ ) and (sand) $p<0.0001$, see Table S8 for post hoc comparisons in Supplementary Materials). Similarly, total damselfish's biomass on occupied colonies (all fish and coral species pooled), averaged $15.3 \mathrm{~g} \pm 2.4$ on sand, and $11.4 \mathrm{~g} \pm 1.8$ on open colonies; values that were three- to four-fold higher than observed on colonies in underhang $(4.9 \mathrm{~g} \pm 0.8)$ and crevice $(3.8 \mathrm{~g} \pm 0.7)$ colony orientations $\left(\mathrm{LM}: \mathrm{F}_{3132}=5.387, p<0.001\right.$, see Table S9 for post hoc comparisons in Supplementary Materials).

\subsection{Colony Structure as a Determinant of Damselfish's Occupation and Biomass}

The PCAs of colony attributes (based on the specific subset of corals and study locations where these attributes were measured) of the five coral-dwelling damselfish (species pooled), revealed distinctive groupings of colonies with and without fish both when data were pooled across coral species, and when analysed separately for each coral species. The first two principal components explained $70 \%$ of variance for all colonies pooled (Table S10 and Figure S4 in Supplementary Materials), and between 55\% and 77\% of variance in colony structure when coral species were analysed individually. Overall, colonies (pooled over species) that were occupied by fish had considerably lower PC1 scores than colonies without fish, and lower PC2 scores (Table S6). In this analysis, PC1 scores were associated with variation in colony diameter and planar areas (dictated by Acropora intermedia colonies), and PC2 scores were driven by branch spacing and colony isolation. When coral colonies were analysed separately by 
individual species (Supplementary Table S11) isolation was the most influential colony variable for all coral species, with branch spacing and planar area as secondary variables.

Total damselfish's biomass per colony followed similar trends with fish occupancy (Table 4 and Table S12 in Supplementary Materials), with isolation and colony height as the most influential colony-structure variables for five of the six coral species, and all structure traits were significant except for branch width, which when analysed individually by species, was only important for Stylophora pistillata. Branch spacing, colony diameter, and planar colony area were significant for three coral species. Branch width was only important for predicting fish biomass present on Stylophora pistillata colonies (Table 4).

Table 4. Series of linear models illustrating variation in total biomass of damselfish in small branching coral colonies (Acropora intermedia, Acropora spathulata, Pocillopora damicornis, Seriatopora hystrix, and Stylophora pistillata), by damselfish (Chromis viridis, Dascyllus aruanus, Dascyllus reticulatus, Pomacentrus amboinensis, and Pomacentrus. moluccensis) for six fine-scale indicators of colony attributes (colony level dataset). The first two traits, colony isolation and branch spacing (shaded), had the highest importance for determining colony occupation. Significant $p$-values are in bold.

\begin{tabular}{|c|c|c|c|c|c|c|c|}
\hline $\begin{array}{c}\text { Coral } \\
\text { Species }\end{array}$ & $n$ & Isolation & $\begin{array}{l}\text { Branch } \\
\text { Spacing }\end{array}$ & $\begin{array}{l}\text { Colony } \\
\text { Diameter }\end{array}$ & 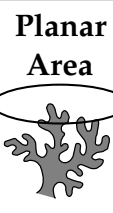 & $\begin{array}{l}\text { Colony } \\
\text { Height }\end{array}$ & $\begin{array}{l}\text { Branch } \\
\text { Width } \\
\text { Oี }\end{array}$ \\
\hline $\begin{array}{c}\text { A. } \\
\text { intermedia }\end{array}$ & 22 & $<0.001$ & 0.527 & 0.019 & $<0.001$ & 0.068 & 0.185 \\
\hline $\begin{array}{c}\text { A. } \\
\text { spathulata }\end{array}$ & 32 & 0.099 & 0.357 & 0.020 & $<0.001$ & 0.008 & 0.416 \\
\hline $\begin{array}{c}P . \\
\text { damicornis }\end{array}$ & 66 & 0.014 & 0.002 & $<0.001$ & $<0.001$ & $<0.001$ & 0.423 \\
\hline S. hystrix & 44 & 0.002 & $<0.001$ & 0.304 & 0.809 & 0.018 & 0.198 \\
\hline S. pistillata & 62 & $<0.001$ & $<0.001$ & 0.734 & 0.357 & 0.015 & $<0.001$ \\
\hline All colonies & 226 & $<0.001$ & 0.007 & $<0.001$ & $<0.001$ & $<0.001$ & 0.176 \\
\hline
\end{tabular}

\section{Discussion}

This research demonstrates substantial variation in the occupancy rates of small-branching coral hosts by five species of coral-dwelling damselfish, with between $0 \%-93 \%$ of coral colonies being occupied per transect, depending on reef habitat zone and exposure. Within habitats, small-scale differences in the morphology and position of coral colonies also contributed to occupancy and biomass of fishes. Previous studies have suggested that variation in coral colony structure and health are likely to play important roles in determining the population dynamics of coral-associated fishes and invertebrates [78,79], as well as the persistence of these fish assemblages. This study provides new insight into the factors that control the presence and abundance of individual symbiotic damselfish species (and associated group biomass, distribution across parts of the GBR) and provides context for understanding the potential impacts of aggregating damselfish on complex networks of reef species and reef ecosystem function.

The overall rates of occupancy reported in this study (30\%) were aspect- and habitat zone-specific, demonstrating patterns of both high occupancy and high biomass on patchy sheltered aspect sites and significantly lower values on continuous, exposed aspect sites. At the transect level, physical conditions of these habitats are congruent with many of the environmental gradients (i.e., water-flow) and niche partitioning requirements that structure damselfish populations $[7,18,35,80]$. These results suggest that generalist damselfish species may be better able to utilise corals as habitat in high-flow environments than other species that are limited to specific coral species which may be more prevalent in sheltered areas $[21,22,41]$. For instance, Pomacentrus moluccensis was the most prevalent damselfish species 
recorded and contributed disproportionally to the fish biomass present on occupied colonies on exposed sites. Consequently, damselfish inhabiting branching corals in exposed or deeper locations may be generalists zooplankton/omnivore feeders with the ability to take advantage of pelagic subsidies [81] rather than more specialized feeders $[34,36,37,82]$. While most coral-dwelling damselfish are found in sheltered habitats (i.e., flow $<21.2 \mathrm{~cm} \mathrm{~s}^{-1}$ ), the body shape and fin morphology of Pomacentrus moluccensis may make them more adapted to higher current velocities, while Dascyllus aruanus may be more suited to lower currents $[40,41]$ and was present on only $14 \%$ of damselfish-occupied corals, nearly all on sheltered sites. As an omnivorous bentho-pelagic feeder, Dascyllus aruanus can consume zooplankton and algae in equal proportions $[34,38]$ which may partially explain its high abundance in slope/base habitats. Environmental factors such as water temperature, salinity, predators, conspecifics, and prey availability are also likely to influence the distribution and abundance of damselfish, independent of the abundance or availability of suitable coral hosts $[34,37,83]$. Although structural complexity and subsequent coral cover are often positively associated with fish biodiversity $[1,4]$, results of this study showed that these two variables did not predict occupancy or biomass of coral-dwelling damselfish that closely associate with corals, consistent with previous studies $[7,9,25,84-86]$. Furthermore, latitude did not significantly affect colony occupancy or biomass; consistent with other studies reporting distribution and abundance of planktivorous damselfish along the Great Barrier Reef [18].

The coral species considered within this study (Acropora intermedia, Acropora spathulata, Pocillopora damicornis, Seriatopora hystrix, and Stylophora pistillata) are among the preferred coral hosts for coral-dwelling damselfish $[21,22,46]$, yet $68 \%$ of colonies were unoccupied. This suggests that either abundance of these damselfish is not limited by coral host availability $[87,88]$, or that there are colony attributes beyond species identity that determine their suitability as host corals [78,89]. This research reveals a suite of factors at small scale $(<1 \mathrm{~m})$ that influence occupation rates, including colony height, and colony position on the benthos, as well as the distance to other potential host corals. These attributes do not necessarily distinguish suitable versus unsuitable microhabitats, but given the choice of host corals, it would be expected that damselfish would select hosts that maximize individual fitness. Colonies with more elevated growth forms, raised above the seafloor, may also enhance fishes' abilities to stay higher in the water column, containing more enriched plankton, yet still close to refuge $[90,91]$. Elevated (high overall height) and isolated colonies, often in open position or on sandy substrates, allow for feeding with reduced danger due to visibility and enhanced colony structure complexity for refuge. Furthermore, damselfish species may respond differently to different species and morphologies of corals, with colony structure likely being more important to small-bodied fish [29,30]. For instance, Dascyllus aruanus prefer colonies with medium open-branch spacing (i.e., Pocillopora damicornis over Acropora intermedia or Acropora spathulata), while Pomacentrus moluccensis showed more equivalent abundance on all colony species. Branch spacing of corals limits occupancy only in tighter branching species (Acropora spathulata, Pocillopora damicornis, and Seriatopora hystrix) and may lead to variations in species interactions [92] between damselfish with their competitors and/or predators, and services (i.e., nutrient retention [26]).

Colony isolation was consistently the most important attribute predicting the presence and biomass of damselfish. Many damselfish species exhibit 'clumped' or 'patchy' distributions, leading to increased fish-coral interactions with increased fish abundance [47]. Sand patch and slope/base habitats, often categorized as edge habitats [43] with lower coral cover, host more fish-coral interactions and allow for more 'open' colonies, rather than nested corals along continuous reefs [39,93]. The isolation and spacing of colonies occupied may allow for: (a) continual use and residency by fish (i.e., distance to nearest available habitat is beyond the fish's home range); (b) increased impacts of association defense and reduction of fish predation [9,94-96]; (c) access to plankton resources and reduced competition [9,97-99]; and (d) larger borders with sandy substrates as an alternative foraging substrate [100]. Competition between damselfish species is also responsible for the ecological partitioning of these species along gradients [98], leading to differential use and fish-derived benefits 
to coral hosts $[9,101]$. Many of these factors may enhance the survival of the coral holobiont in select habitats.

Coral occupancy of $30 \%$ may be an underestimate, as it excludes additional common fish families that can inhabit coral colonies (i.e., Apogonidae, Gobiidae, Haemulidae), and coral sizes $(>100 \mathrm{~cm})$, and coral species (i.e., Porites and Echinopora). While damselfish are present in many coral reef habitats [18], fish-coral interactions may vary in the sign or magnitude of the effect on their coral host $[47,92]$, with sand patch, and slope/base zones acting as small-scale interaction hotspots with high occupancy and biomass patterns. These hotspots, areas of high localized nutrient production by fishes $[28,102]$ are generally infrequent across seascapes. Nutrient subsidy, along with other fish-derived services like increased photosynthesis [103], colony growth [28], bleaching susceptibility [27] sediment removal [101], may be density-dependent (i.e., $>15 \mathrm{~g}$ seen in studies focusing on larger-bodied or more abundant fish species, see $[26,104,105])$ and fish-species dependent. With $68 \%$ of corals vacant, it is clear that many colonies do not receive potential beneficial effects of resident damselfish. However, certain provided benefits, such as increased oxygen input [103] or nutrients [26], may be more necessary within specific habitats (i.e., deeper sand patch and slope habitats) or under specific environmental conditions (i.e., low-flow habitats [47]), thereby having a stronger impact on coral health for a smaller proportion of the population. Finally, different coral species have important effects on the biodiversity and function of resident fishes, with several colony structure traits directly associated with fish-derived services (i.e., hosting fish, retention of nutrients [25]).

By analyzing the occupancy and biomass of damselfish, one of the most abundant reef fish families that make an important contribution to reef food webs [34], this research illustrates that both large-scale features of reef habitats and fine-scale coral morphological traits contribute to fish-coral association. Several coral-dwelling damselfish species are constrained to certain reef habitats likely due to the physical constraints of the habitat, such as high-water energy. However, even after accounting for extrinsic factors, there are important colony traits that influence colony use. Clearly, studies of coral-associated fauna across multiple spatial scales [30] that go beyond simply quantifying fauna presence-absence are necessary to understand the population dynamics of corals and symbiotic fauna. Quantifying the establishment and maintenance of such symbiotic associations with scleractinian corals will be essential to predicting how these complex networks operate under global environmental stress [83]. Indeed, many of these branching coral species, particularly, Seriatopora hystrix, which hosts the highest damselfish biomass, are the species most vulnerable to global climate change [51,106]; the loss of these coral species will reduce considerably the habitat for small-bodied fishes [22]. Moreover, the high degree of spatial variation in the strength of fish-coral interactions and other symbiotic interactions will make it challenging to predict their ecological functioning and cost-benefit ratios.

Supplementary Materials: The following are available online at http://www.mdpi.com/1424-2818/11/11/219/s1; Figure S1: Focal coral-fish interactions of this study focused on (a-e) five common small-branching coral species, Figure S2: Illustration of 7 coral colony structure attributes for five species of branching colonies $(15-100 \mathrm{~cm}$ diameter) for 226 colonies over 15 sites on 11 reefs, Figure S3: Average biomass ( \pm SE) of damselfishes per occupied colony on the different reef habitat zones, Figure S4: Principal component analysis (PCA) of coral colony structure attributes for $n=216$ branching corals with and without resident damselfishes along mid-shelf and off-shore reefs of the GBR; Table S1: Relative importance of environmental variables influencing fish-coral interactions (reef seascape level), based on MuMIn model selection and model averaging, with Akaike information criteria (AICc) weighting schemes, Table S2: Binomial generalized linear model (GLM) output for fishes (species pooled) occupation by coral species (reef seascape level dataset), Table S3: Descriptive statistics of reef seascape biomass estimated (mean grams \pm SE) for each damselfish species and total biomass pooled for all coral species (per occupied colony of Acropora intermedia, Acropora spathulata, Pocillopora damicornis, Seriatopora hystrix, and Stylophora pistillata) by site aspect (sheltered or exposed), Table S4: Descriptive statistics of reef seascape biomass estimated (mean grams \pm SE) for each damselfish species (Chromis viridis, Dascyllus aruanus, Dascyllus reticulatus, Pomacentrus amboinensis, and Pomacentrus moluccensis) and total biomass pooled for all coral species, Table S5: Average reef seascape biomass estimates (mean \pm SE) for each damselfish species (Chromis viridis, Dascyllus aruanus, Dascyllus reticulatus, Pomacentrus amboinensis, and Pomacentrus moluccensis) on each coral species, Table S6: Multiple comparisons of coral-species, with $p$-values, (Tukey's HSD post hoc) based on a Gaussian generalized linear model of total damselfish biomass, Table S7: Multiple coral species comparisons 
with $p$-values (post hoc Dunn test for (Benjamini-Hochberg method based off a Kruskal-Wallis rank sum test) for each damselfish species (damselfish-species specific biomass) for only occupied colonies, Table S8: Tukey's HSD post hoc test for multiple comparisons of position of coral on benthos, with $p$-values, based on a binomial generalized linear model of damselfish presence with damselfish species pooled, Table S9: Tukey's HSD post hoc test for multiple comparisons of position of coral on benthos, with $p$-values, based on a lognormal linear model of total biomass with damselfish species pooled for only occupied colonies, Table S10: Variance explained and linear models displaying differences between coral colonies with and without fish along principal component analyses PC1 and PC2, for a subset of coral colonies $(n=226)$ at 15 different sites on 11 reefs, Table S11: Similarity percentage analysis (SIMPER) results displaying the cumulative contributions of the most influential colony structure variables on coral colony occupation (presence or absence) by damselfishes, Table S12: Series of linear models illustrating variation in damselfishes' occupancies on small-branching coral colonies.

Author Contributions: Conceptualization, methodology, data collection, formal analysis, resources, data curation, writing-original draft preparation, writing-review and editing, visualization, project administration, funding acquisition all completed by T.JC. and M.OH.

Funding: This research was funded by the Australian Research Council to the ARCCOE for Coral Reef Studies CE140100020 and James Cook University. The funders have no role in study design, data collection and analysis, decision to publish, or preparation of the manuscript.

Acknowledgments: We thank Lizard Island staff, Grace Frank, Margaux Hein, Saskia Jurriaans, Sterling Tebbett, Andrew Baird, and the crew of the RV Kalinda for their field support and assistance. This project was implemented in accordance with the Great Barrier Reef Marine Park Authority permit (G15/37657.1, G15/37950.1, and G16/38437.1), James Cook University Animal Ethics Permit (A2186 and A2207), and James Cook University's General Fisheries Permit (170251).

Conflicts of Interest: The authors declare no conflict of interest.

\section{References}

1. Graham, N.A.J.; Nash, K.L. The importance of structural complexity in coral reef ecosystems. Coral Reefs 2013, 32, 315-326. [CrossRef]

2. Bell, J.; Galzin, R. Influence of live coral cover on coral-reef fish communities. Mar. Ecol. Prog. Ser. 1984, 15, 265-274. [CrossRef]

3. Roberts, C.; Ormond, R. Habitat complexity and coral reef fish diversity and abundance on Red Sea fringing reefs. Mar. Ecol. Prog. Ser. 1987, 41,1-8. [CrossRef]

4. Friedlander, A.M.; Parrish, J.D. Habitat characteristics affecting fish assemblages on a Hawaiian coral reef. J. Exp. Mar. Bio. Ecol. 1998, 224, 1-30. [CrossRef]

5. Sale, P. Extremely Limited Home Range in a Coral Reef Fish, Dascyllus aruanus (Pisces; Pomacentridae). Copeia 1971, 1971, 324-327. [CrossRef]

6. Munday, P.L.; Jones, G.P.; Caley, M.J. Habitat specialisation and the distribution and abundance of coral-dwelling gobies. Mar. Ecol. Prog. Ser. 1997, 152, 227-239. [CrossRef]

7. Wilson, S.; Burgess, S.; Cheal, A.; Emslie, M.; Fisher, R.; Miller, I.; Polunin, N. Habitat utilization by coral reef fish: implications for specialists vs. generalists in a changing environment. J. Anim. Ecol. 2007, 77, $220-228$. [CrossRef]

8. Feary, D.A. The influence of resource specialization on the response of reef fish to coral disturbance. Mar. Biol. 2007, 153, 153-161. [CrossRef]

9. Komyakova, V.; Munday, P.L.; Jones, G.P. Relative importance of coral cover, habitat complexity and diversity in determining the structure of reef fish communities. PLoS ONE 2013, 8, e83178. [CrossRef]

10. Graham, N.A.J.; Wilson, S.K.; Jennings, S.; Polunin, N.V.C.; Bijoux, J.P.; Robinson, J. Dynamic fragility of oceanic coral reef ecosystems. Proc. Natl. Acad. Sci. USA 2006, 103, 8425-8429. [CrossRef]

11. Wilson, S.K.; Graham, N.A.J.; Pratchett, M.S.; Jones, G.P.; Polunin, N.V.C. Multiple disturbances and the global degradation of coral reefs: Are reef fishes at risk or resilient? Glob. Chang. Biol. 2006, 12, $2220-2234$. [CrossRef]

12. Kramer, M.J.; Bellwood, D.R.; Taylor, R.B.; Bellwood, O. Benthic crustacea from tropical and temperate reef locations: Differences in assemblages and their relationship with habitat structure. Coral Reefs 2017, 36, 971-980. [CrossRef]

13. Messmer, V.; Jones, G.P.; Munday, P.L.; Holbrook, S.J.; Schmitt, R.J.; Brooks, A.J. Habitat biodiversity as a determinant of fish community structure on coral reefs. Ecology 2011, 92, 2285-2298. [CrossRef] [PubMed] 
14. Beukers, J.; Jones, J. Habitat complexity modifies the impact of piscivores on a coral reef fish population. Oecologia 1997, 114, 50-59. [CrossRef]

15. Almany, G.R. Differential effects of habitat complexity, predators and competitors on abundance of juvenile and adult coral reef fishes. Oecologia 2004, 141, 105-113. [CrossRef]

16. Munday, P.; Jones, G.; Caley, J. Interspecific competition and coexistence in a guild of coral-dwelling fishes. Ecology 2001, 82, 2177-2189. [CrossRef]

17. Cole, A.J.; Pratchett, M.S.; Jones, G.P. Diversity and functional importance of coral-feeding fishes on tropical coral reefs. Fish Fish 2008, 9, 286-307. [CrossRef]

18. Emslie, M.J.; Logan, M.; Cheal, A.J. The Distribution of planktivorous damselfishes (Pomacentridae) on the Great Barrier Reef and the relative influences of habitat and predation. Diversity 2019, 11, 33. [CrossRef]

19. Jones, G.P.; McCormick, M.I.; Srinivasan, M.; Eagle, J.V. Coral decline threatens fish biodiversity in marine reserves. Proc. Natl. Acad. Sci. USA 2004, 101, 8251-8253. [CrossRef]

20. Booth, D.J.; Wellington, G. Settlement preferences in coral-reef fishes: Effects on patterns of adult and juvenile distributions, individual fitness and population structure. Aust. J. Ecol. 1998, 23, 274-279. [CrossRef]

21. Holbrook, S.J.; Forrester, G.E.; Schmitt, R.J. Spatial patterns in abundance of damselfish reflect availability of suitable habitat. Oecologia 2000, 122, 109-120. [CrossRef] [PubMed]

22. Pratchett, M.S.; Coker, D.J.; Jones, G.P.; Munday, P.L. Specialization in habitat use by coral reef damselfishes and their susceptibility to habitat loss. Ecol. Evol. 2012, 2, 2168-2180. [CrossRef] [PubMed]

23. Munday, P.L. Does habitat availability determine geographical-scale abundances of coral-dwelling fishes? Coral Reefs 2002, 21, 105-116. [CrossRef]

24. Mellin, C.; Bradshaw, C.; Meekan, M.; Caley, M. Environmental and spatial predictors of species richness and abundance in coral reef fishes. Glob. Ecol. Biogeogr. 2019, 19, 212-222. [CrossRef]

25. Darling, E.S.; Graham, N.A.J.; Januchowski-Hartley, F.A.; Nash, K.L.; Pratchett, M.S.; Wilson, S.K. Relationships between structural complexity, coral traits, and reef fish assemblages. Coral Reefs 2017, 36, 561-575. [CrossRef]

26. Holbrook, S.J.; Brooks, A.J.; Schmitt, R.J.; Stewart, H.L. Effects of sheltering fish on growth of their host corals. Mar. Biol. 2008, 155, 521-530. [CrossRef]

27. Chase, T.; Pratchett, M.; Frank, G.; Hoogenboom, M. Coral-dwelling fish moderate bleaching susceptibility of coral hosts. PLoS ONE 2018, 13, e0208545. [CrossRef]

28. Meyer, J.; Schultz, E.; Helfman, G. Fish Schools: An Asset to Corals. Science 1983, 220, 1047-1049. [CrossRef]

29. Kane, C.N.; Brooks, A.J.; Holbrook, S.J.; Schmitt, R.J. The role of microhabitat preference and social organization in determining the spatial distribution of a coral reef fish. Environ. Biol. Fishes 2009, 84, 1-10. [CrossRef]

30. Nash, K.L.; Graham, N.A.J.; Wilson, S.K.; Bellwood, D.R. Cross-scale habitat structure drives fish body size distributions on coral reefs. Ecosystems 2013, 16, 478-490. [CrossRef]

31. Epstein, H.E.; Kingsford, M.J. Are soft coral habitats unfavourable? A closer look at the association between reef fishes and their habitat. Environ. Biol. Fishes 2019, 102, 479-497. [CrossRef]

32. Bay, L.; Jones, G.; McCormick, M. Habitat selection and aggression as determinants of spatial segregation among damselifsh on a coral reef. Coral Reefs 2001, 20, 289-298.

33. Sale, P.F. Appropriate spatial scales for studies of reef-fish ecology. Austral. Ecol. 1998, 23, 202-208. [CrossRef]

34. Frédérich, B.; Fabri, G.; Lepoint, G.; Vandewalle, P.; Parmentier, E. Trophic niches of thirteen damselfishes (Pomacentridae) at the Grand Récif of Toliara, Madagascar. Ichthyol. Res. 2009, 56, 10-17. [CrossRef]

35. Gajdzik, L.; Parmentier, E.; Michel, L.N.; Sturaro, N.; Soong, K.; Lepoint, G.; Frédérich, B. Similar levels of trophic and functional diversity within damselfish assemblages across Indo-Pacific coral reefs. Funct. Ecol. 2018, 32, 1358-1369. [CrossRef]

36. McMahon, K.W.; Thorrold, S.R.; Houghton, L.A.; Berumen, M.L. Tracing carbon flow through coral reef food webs using a compound-specific stable isotope approach. Oecologia 2016, 180, 809-821. [CrossRef]

37. Wyatt, A.S.J.; Waite, A.M.; Humphries, S. Stable isotope analysis reveals community-level variation in fish trophodynamics across a fringing coral reef. Coral Reefs 2012, 31, 1029-1044. [CrossRef]

38. Gajdzik, L.; Parmentier, E.; Sturaro, N.; Frédérich, B. Trophic specializations of damselfishes are tightly associated with reef habitats and social behaviours. Mar. Biol. 2016, 163, 1-15. [CrossRef]

39. Nadler, L.E.; McNeill, D.C.; Alwany, M.A.; Bailey, D.M. Effect of habitat characteristics on the distribution and abundance of damselfish within a Red Sea reef. Environ. Biol. Fishes 2014, 97, 1265-1277. [CrossRef] 
40. Fulton, C.J.; Bellwood, D.R.; Wainwright, P.C. Wave energy and swimming performance shape coral reef fish assemblages. Proc. R. Soc. B Biol. Sci. 2005, 272, 827-832. [CrossRef]

41. Johansen, J.L.; Bellwood, D.R.; Fulton, C.J. Coral reef fishes exploit flow refuges in high-flow habitats. Mar. Ecol. Prog. Ser. 2008, 360, 219-226. [CrossRef]

42. Fulton, C.J.; Bellwood, D.R. Wave-induced water motion and the functional implications for coral reef fish assemblages. Limnol. Oceanogr. 2005, 50, 255-264. [CrossRef]

43. Sambrook, K.; Jones, G.P.; Bonin, M.C. Life on the edge: Coral reef fishes exhibit strong responses to a habitat boundary. Mar. Ecol. Prog. Ser. 2016, 561, 203-215. [CrossRef]

44. Kerry, J.T.; Bellwood, D.R. The effect of coral morphology on shelter selection by coral reef fishes. Coral Reefs 2012, 31, 415-424. [CrossRef]

45. Pratchett, M.S.; Baird, A.H.; McCowan, D.M.; Coker, D.J.; Cole, A.J.; Wilson, S.K. Protracted declines in coral cover and fish abundance following climate-induced coral bleaching on the Great Barrier Reef. In Proceedings of the 11th International Coral Reef Symposium, Fort Lauderdale, FL, USA, 7-11 July 2008; pp. 1309-1313.

46. Coker, D.; Wilson, S.; Pratchett, M. Importance of live coral habitat for reef fishes. Rev. Fish Biol. Fish. 2014, 24, 89-126. [CrossRef]

47. Chase, T.; Pratchett, M.; Walker, S.; Hoogenboom, M. Small-scale environmental variation influences whether coral-dwelling fish promote or impede coral growth. Oecologia 2014, 176, 1009-1022. [CrossRef]

48. Randall, J.; Allen, G.; Steene, R. Fishes of the Great Barrier Reef and Coral Sea; University of Hawai'i Press: Honolulu, HI, USA, 1997.

49. Allen, G.; Steene, R.; Humann, P.; DeLoach, N. Reef Fish Identification-Tropical Pacific; New World Pulications, Inc.: Jacksonville, FL, USA, 2003.

50. Chase, T.; Pratchett, M.; Hoogenboom, M. Behavioural trade-offs and habitat associations of coral-dwelling damselfishes (family Pomacentridae). Mar. Ecol. Prog. Ser. 2019. [CrossRef]

51. Hughes, T.P.; Kerry, J.T.; Álvarez-Noriega, M.; Álvarez-Romero, J.G.; Anderson, K.D.; Baird, A.H.; Babcock, R.C.; Beger, M.; Bellwood, D.R.; Berkelmans, R.; et al. Global warming and recurrent mass bleaching of corals. Nature 2017, 543, 373-377. [CrossRef]

52. Hoogenboom, M.O.; Frank, G.E.; Chase, T.J.; Jurriaans, S.; Álvarez-Noriega, M.; Peterson, K.; Critchell, K.; Berry, K.L.E.; Nicolet, K.J.; Ramsby, B.; et al. Environmental drivers of variation in bleaching severity of Acropora species during an extreme thermal anomaly. Front. Mar. Sci. 2017, 4, 376. [CrossRef]

53. Graham, N.A.J.; Chong-Seng, K.M.; Huchery, C.; Januchowski-Hartley, F.A.; Nash, K.L. Coral reef community composition in the context of disturbance history on the Great Barrier Reef, Australia. PLoS ONE 2014, 9. [CrossRef]

54. Hopley, D.; Smithers, S.; Parnell, K. The Geomorphology of the Great Barrier Reef: Development, Diversity and Change; Cambridge University Press: Cambridge, UK, 2007.

55. Ménard, A.; Turgeon, K.; Roche, D.G.; Binning, S.A.; Kramer, D.L. Shelters and their use by fishes on fringing coral reefs. PLoS ONE 2012, 7. [CrossRef]

56. Veron, J.; Stafford-Smith, M. Corals of the World; Australian Institute of Marine Science: Townsville, Australia, 2004.

57. Hill, J.; Wilkinson, C. Methods for Ecological Monitoring of Coral Reefs; Australian Institute of Marine Science: Townsville, Australia, 2004; 117p.

58. Wehrberger, F.; Herler, J. Microhabitat characteristics influence shape and size of coral-associated fishes. Mar. Ecol. Prog. Ser. 2014, 500, 203-214. [CrossRef]

59. Fernandes, I.M.; Bastos, Y.F.; Barreto, D.S.; Lourenço, L.S.; Penha, J.M. The efficacy of clove oil as an anaesthetic and in euthanasia procedure for small-sized tropical fishes. Braz. J. Biol. 2016, 77, 444-450. [CrossRef]

60. Javahery, S.; Nekoubin, H.; Moradlu, A.H. Effect of anaesthesia with clove oil in fish (review). Fish Physiol. Biochem. 2012, 38, 1545-1552. [CrossRef]

61. Burkepile, D.E.; Allgeier, J.E.; Shantz, A.A.; Pritchard, C.E.; Lemoine, N.P.; Bhatti, L.H.; Layman, C.A. Nutrient supply from fishes facilitates macroalgae and suppresses corals in a Caribbean coral reef ecosystem. Sci. Rep. 2014, 3, 19-21. [CrossRef]

62. Cribari-Neto, F.; Zeileis, A. Journal of Statistical Software Beta Regression in R. J. Stat. Softw. 2010, 34, 1-24. [CrossRef] 
63. Warton, D.I.; Hui, F. The arcsine is asinine: The analysis of proportions in ecology. Ecology 2011, 92, 3-10. [CrossRef]

64. Affleck, D.L.R. Additivity and maximum likelihood estimation of nonlinear component biomass models. In Proceedings of the New Directions in Inventory Techinques \& Applicaitons Forest Inventory \& Analysis (FIA) Symposium 2015, 8-12 December 2015; U.S. Department of Agriculture, Forest Service, Pacific Northwest Research Station: Portland, OR, USA; pp. 13-17.

65. Zuur, A.; Ieno, E.; Walker, N.; Saveliev, A.; Smith, G. Mixed Effects Models and Extension in Ecology with R; Springer: New York, NY, USA, 2009.

66. Zuur, A.F.; Ieno, E.N. A protocol for conducting and presenting results of regression-type analyses. Methods Ecol. Evol. 2016, 7, 636-645. [CrossRef]

67. Bartón, K. MuMIN: Multi-model Interference R Package Version 1.9.12; The R Foundation: Vienna, Austria, 2013.

68. Burnham, K.P.; Anderson, D.R. Multimodel Inference: Understanding AIC and BIC in Model Selection, 2nd ed.; Springer: New York, NY, USA, 2002.

69. Benjamini, Y.; Hochber, Y. Controlling the false discovery rate: A practical and powerful approach to multiple testing. J. R. Stat. Soc. B 1995, 57, 289-300. [CrossRef]

70. Venables, W.; Ripley, B. Modern Applied Statistics with S, 4th ed.; Springer: Berlin, Germany, 2002.

71. Mardia, K.; Kent, J.; Bibby, J. Multivariate Analysis; Academic Press: London, UK, 1979.

72. Clarke, K.R. Non-parametric multivariate analyses of changes in community structure. Aust. J. Ecol. 1993, 18, 117-143. [CrossRef]

73. Warton, D.I.; Wright, S.T.; Wang, Y. Distance-based multivariate analyses confound location and dispersion effects. Methods Ecol. Evol. 2012, 3, 89-101. [CrossRef]

74. R Development Core Team. R: A Language and Environment for Statistical Computing; The R Foundation: Vienna, Austria, 2018.

75. Hothorn, T.; Bretz, F.; Westfall, P. Simulatnous Inference in Generall Parametric Models. Biom. J. 2008, 50, 346-363. [CrossRef] [PubMed]

76. Lenth, R.V. Least-Squares Means: The R Package lsmeans. J. Stat. Softw. 2016, 69, 1-33. [CrossRef]

77. Chase, T.; Hoogenboom, M. Occupation of Damselfishes across Reef Seascape and Colony Scale, GBR 2016 Data. James Cook University (Dataset). Available online: http://dx.doi.org/10.25903/5dcb4c44aa86a (accessed on 19 November 2019).

78. Noonan, S.H.C.; Jones, G.P.; Pratchett, M.S. Coral size, health and structural complexity: Effects on the ecology of a coral reef damselfish. Mar. Ecol. Prog. Ser. 2012, 456, 127-137. [CrossRef]

79. Pereira, P.H.C.; Munday, P.L. Coral colony size and structure as determinants of habitat use and fitness of coral-dwelling fishes. Mar. Ecol. Prog. Ser. 2016, 553, 163-172. [CrossRef]

80. Waldner, R.E.; Robertson, D.R. Patterns of habitat partitioning by eight species of territorial caribbean damselfishes (Pisces: Pomacentridae). Bull. Mar. Sci. 1980, 30, 171-186.

81. Morais, R.A.; Bellwood, D.R. Pelagic Subsidies Underpin Fish Productivity on a Degraded Coral Reef. Curr. Biol. 2019, 29, 1521-1527.e6. [CrossRef]

82. Meekan, M.G.; Steven, A.D.L.; Fortin, M.J. Spatial patterns in the distribution of damselfishes on a fringing coral reef. Coral Reefs 1995, 14, 151-161. [CrossRef]

83. Waldock, C.; Stuart-Smith, R.D.; Edgar, G.J.; Bird, T.J.; Bates, A.E. The shape of abundance distributions across temperature gradients in reef fishes. Ecol. Lett. 2019, 22, 685-696. [CrossRef]

84. Ault, T.; Johnson, C. Spatial variation in fish species richness on coral reefs: Habitat fragmentation and stochastic structuring processes. Okios 1998, 82, 354-364. [CrossRef]

85. Bergman, K.C.; Öhman, M.C.; Svensson, S. Influence of habitat structure on Pomacentrus sulfureus, a western Indian Ocean reef fish. Environ. Biol. Fishes 2000, 59, 243-252. [CrossRef]

86. Maire, E.; Villeger, S.; Graham, N.A.J.; Hoey, A.S.; Cinner, J.; Ferse, S.C.A.; Aliaume, C.; Booth, D.J.; Feary, D.A.; Kulbicki, M.; et al. Community-wide scan identifies fish species associated with coral reef services across the Indo-Pacific. Proc. R. Soc. B Biol. Sci. 2018, 285, 1621-1629. [CrossRef]

87. Doherty, P.; Fowler, T. An empirical test of recruitment limitation in a coral reef fish. Science 1994, 263, 935-939. [CrossRef]

88. Forrester, G. Strong density-dependent survival and recruitment regulate the abundance of a coral reef fish. Oecologia 1995, 103, 275-282. [CrossRef] 
89. Holbrook, S.J.; Schmitt, R.J. Spatial and temporal variation in mortality of newly settled damselfish: Patterns, causes and co-variation with settlement. Oecologia 2003, 135, 532-541. [CrossRef]

90. Motro, R.; Ayalon, I.; Genin, A. Near-bottom depletion of zooplankton over coral reefs: III: Vertical gradient of predation pressure. Coral Reefs 2005, 24, 95-98. [CrossRef]

91. Zikova, A.V.; Britaev, T.A.; Ivanenko, V.N.; Mikheev, V.N. Planktonic and symbiotic organisms in nutrition of coralobiont fish. J. Ichthyol. 2011, 51, 769-775. [CrossRef]

92. Chamberlain, S.A.; Bronstein, J.L.; Rudgers, J.A. How context dependent are species interactions? Ecol. Lett. 2014, 17, 881-890. [CrossRef]

93. Nanami, A.; Nishihira, M. Effects of habitat connectivity on the abundance and species richness of coral reef fishes: Comparison of an experimental habitat established at a rocky reef flat and at a sandy sea bottom. Environ. Biol. Fishes 2003, 68, 183-196. [CrossRef]

94. Shpigel, M.; Fishelson, L. Behavior and physiology of coexistence in two species of Dascyllus (Pomacentridae, Teleostei). Environ. Biol. Fishes 1986, 17, 253-265. [CrossRef]

95. Sale, P.F. Effect of cover on agonistic behavior of a reef fish: A possible spacing mechanism. Ecolgoy 1972, 53, 753-758. [CrossRef]

96. Sale, P.F. Influence of corals in the dispersion of the Pomacentrid fish, Dascyllus aruanus. Ecology 1972, 53, 741-744. [CrossRef]

97. Pratchett, M.; Hoey, A.; Wilson, S.; Hobbs, J.; Allen, G. Habitat-use and specialisation among coral reef damselfishes. In Biology of Damselfishes; Frédérich, B., Parmentier, E., Eds.; CRC Press: Boca Raton, FL, USA, 2016; pp. 84-121.

98. Eurich, J.; McCormick, M.; Jones, G. Habitat selection and aggression as determinants of fine-scale partitioning of coral reef zones in a guild of territorial damselfishes. Mar. Ecol. Prog. Ser. 2018, 587, 201-215. [CrossRef]

99. Almany, G.R. Does increased habitat complexity reduce predation and competition in coral reef fish assemblages? Oikos 2004, 106, 275-284. [CrossRef]

100. Wen, C.K.C.; Pratchett, M.S.; Almany, G.R.; Jones, G.P. Patterns of recruitment and microhabitat associations for three predatory coral reef fishes on the southern Great Barrier Reef, Australia. Coral Reefs 2013, 32, 389-398. [CrossRef]

101. Chase, T. Effects of Coral-Dwelling Damselfishes' Abundances and Diversity on Host Coral Dynamics; James Cook University: Townsvile, Australia, 2019.

102. Shantz, A.A.; Ladd, M.C.; Schrack, E.; Burkepile, D.E. Fish-derived nutrient hotspots shape coral reef benthic communities. Ecol. Appl. 2015, 25, 2142-2152. [CrossRef]

103. Garcia-Herrera, N.; Ferse, S.C.A.; Kunzmann, A.; Genin, A. Mutualistic damselfish induce higher photosynthetic rates in their host coral. J. Exp. Biol. 2017, 220, 1803-1811. [CrossRef]

104. Meyer, J.L.; Schultz, E.T. Migrating haemulid fishes as a source of nutrients and organic matter on coral reefs. Limnol. Oceanogr. 1985, 30, 146-156. [CrossRef]

105. Meyer, J.; Schultz, E. Tissue condition and growth rate of corals associated with schooling fish. Limnol. Oceanogr. 2019, 30, 157-166. [CrossRef]

106. Hoegh-Guldberg, O.; Smith, G.J. The effect of sudden changes in temperature, light and salinity on the population density and export of zooxanthellae from the reef corals Stylophora pistillata Exper and Seriatopora hystrix Dana. J. Exp. Mar. Biol. Ecol. 1989, 129, 279-303. [CrossRef]

(C) 2019 by the authors. Licensee MDPI, Basel, Switzerland. This article is an open access article distributed under the terms and conditions of the Creative Commons Attribution (CC BY) license (http://creativecommons.org/licenses/by/4.0/). 